\title{
Model Numerik 1D Penggerusan Endapan di Mulut Muara dengan Metode Beda Hingga
}

\section{One Dimensional Numerical Model to Flushing Sediment at River Mouth with Difference Method}

\author{
Dalrino, Mukhlis \& Elvi Roza Syofyan \\ Jurusan Teknik Sipil, Politeknik Negeri Padang \\ Telp. 0751-72590 Fax. 0751-72576 Email : dalrino350@gmail.com
}

\begin{abstract}
Sedimentation at estuary river have potency to cause floods because the narrowing of estuary as outlet. Sedimentation process can be caused by the so small river discharge at dry season so that cannot to flushing the sediment that happened at estuary mouth. When the rains arrive, river discharge which starting to big shall no long castaway to sea freely, so that causes floods in headwaters. Numerical simulation by using finite different method with Preissmann implicit scheme conducted to see ability of river discharge in early the rains to flushing the sediment in estuary mouth. Simulation was done at river with sediment elevation at + $4.00 \mathrm{~m}$ in estuary mouth.

Boundary condition in the form of discharge hydrograph in early the rains at upstream boundary and also critical water surface elevation in sediment top and sea level at downstream boundary applied at model to see behavior of sediment transport and change of profile at bottom channel that happened. Simulation result show with 24 hours floods charge in early the rains, sediment volume of flushed equal to 20,52\%, with elevation reside at $+3,179 \mathrm{~m}$. Sediment will fully under sea-water face after 9 days simulation. Change of upriver discharge and tidal elevation at downstream will influence to speed of stream that happened. By the end of simulation, the bottom profile of channel influenced of tide.
\end{abstract}

Keywords: Numerical model, flushing, sediment, river mouth.

\section{PENDAHULUAN}

Salah satu permasalahan pada muara sungai yang banyak terjadi di Indonesia adalah proses pendangkalan akibat sedimentasi. Pendangkalan yang bisa berakibat pada penutupan muara sungai tersebut dapat disebabkan karena adanya angkutan sedimen sejajar pantai dan angkutan sedimen sungai. Pendangkalan pada muara sungai berpotensi menyebabkan banjir karena menyempitnya penampang muara sebagai outlet. Ketika musim hujan tiba debit sungai yang mulai membesar tidak lagi bisa terbuang ke laut dengan bebas sehingga menyebabkan banjir di daerah hulu.

Adanya endapan akibat sedimentasi di mulut muara akan menyebabkan terjadinya proses pembendungan pada aliran sungai sehingga mengakibatkan bertambahnya tinggi elevasi muka air di daerah hulu. Debit aliran yang tertahan kemudian akan meluap melewati puncak endapan dan mengalir ke arah laut dengan kedalaman aliran di atas puncak endapan merupakan kedalaman kritis sebagai fungsi debit yang melewatinya. Karena kecepatan aliran di atas puncak endapan lebih besar dibandingkan pada daerah hulu menyebabkan volume material dasar di puncak endapan yang terbawa oleh aliran lebih besar pula sehingga endapan mengalami proses penggerusan. Pada bagian hilir yang langsung berbatasan dengan air laut, kecepatan aliran akan didominasi oleh pasang surut yang terjadi. Hal ini akan menyebabkan perubahan dasar yang berfluktuasi mengikuti pasang surut. Penelitian ini bertujuan untuk memodelkan penggerusan sedimen dasar pada mulut muara dengan menggunakan metode finite difference. Hasil yang ingin diketahui adalah lama waktu penggerusan akibat besaran 
hidrograf banjir rencana pada awal musim hujan dan profil dasar sungai setelah simulasi akibat debit dari hulu dan pasang surut di hilir. Hasil yang diperoleh dari studi ini diharapkan dapat memberikan gambaran tentang kemampuan debit banjir rencana menggerus endapan di mulut muara yang kemudian dapat digunakan sebagai bahan pertimbangan dalam penanganan masalah penutupan muara sungai, dalam kaitannya dengan pengendalian banjir pada daerah hulu muara.

Proses sedimentasi dapat dibedakan atas tiga keadaan, yaitu erosi (erosion), seimbang (equilibrium) dan pengendapan (deposition / silting). Proses tersebut akan menyebabkan keadaan dasar yang berbeda pula, yaitu stabil, degradasi dan agradasi. Gambaran atas proses sedimentasi dan keadaan dasar tersebut dapat dijelaskan pada Gambar 1 dan Tabel 1 di bawah ini (P. Mardjikoen, 1987, B.A Kironoto, 1999).

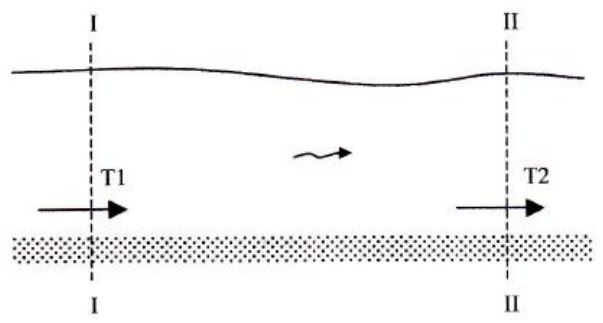

Gambar 1. Transpor sedimen pada tampang panjang saluran.

Tabel 1. Proses Sedimen-Dasar.

\begin{tabular}{|l|l|l|}
\hline \multirow{2}{*}{} & \multicolumn{2}{|c|}{ Proses } \\
\cline { 2 - 3 } & Sedimen & \multicolumn{1}{c|}{ Dasar } \\
\hline $\mathrm{T} 1=\mathrm{T} 2$ & Seimbang & Stabil \\
\hline $\mathrm{T} 1<\mathrm{T} 2$ & Erosi & Degradasi \\
\hline $\mathrm{T} 1>\mathrm{T} 2$ & Pengendapan & Agradasi \\
\hline
\end{tabular}

Model penelusuran aliran air dan sedimen diaplikasikan untuk menginvestigasi konfigurasi dasar saluran dan kedalaman air. Persamaan dasar yang digunakan pada model penelusuran aliran air dan angkutan sedimen adalah persamaan kontinuitas aliran, momentum aliran, kontinuitas sedimen dan persamaan angkutan sedimen. Aliran yang terjadi di sebelah hulu puncak endapan didekati sebagai aliran tidak permanen 1-D dengan menggunakan persamaan yang dikembangkan oleh Barre de St. Venant (1887). Persamaan tersebut memperlihatkan kondisi aliran yang dinyatakan oleh dua variabel tak bebas, yaitu tinggi muka air (y) dan debit (Q) pada setiap titik di saluran untuk setiap waktu (t). Untuk menyelesaikan dua variabel tak bebas tersebut diperlukan dua persamaan, yaitu persamaan kontinuitas (hukum kekekalan massa) dan persamaan momentum (hukum kekekalan momentum) (Budi Wignyosukarto, 1988).

Prinsip kontinuitas menyatakan bahwa jumlah pertambahan volume sama dengan besarnya aliran netto yang lewat pada suatu pias, sehingga didapat persamaan kontinuitas sebagai berikut :

$\frac{\partial}{\partial t} A+\frac{\partial}{\partial x} Q=0$

Hukum kekekalan momentum yang dinyatakan dalam persamaan momentum sebenarnya adalah penjabaran dari gaya-gaya dan momentum yang bekerja pada air dalam volume kontrol, sehingga menyebabkan air tersebut mengalir (Djoko Luknanto, 1992).

Persamaan momentum dapat ditulis sebagai :

$\frac{\partial Q}{\partial t}+2 \alpha\left(\frac{Q}{A}\right) \frac{\partial Q}{\partial x}-\alpha\left(\frac{Q}{A}\right)^{2}\left(\frac{\partial A}{\partial x}\right)+g A\left(\frac{\partial y}{\partial x}\right)+$

g.A.S $f=0$

dengan $Q$ adalah debit, $x$ adalah panjang saluran, $A$ adalah luas tampang basah, $t$ adalah waktu, $\alpha$ adalah koefisien Coriolis, $y$ adalah elevasi muka air, $g$ adalah percepatan gravitasi dan $S_{f}$ kemiringan garis energi.

Pada bagian hilir puncak endapan aliran yang terjadi dianggap sebagai aliran permanen, dengan perubahan tinggi elevasi muka air mengikuti bentuk persamaan aliran permanen sebagai berikut ( Bambang Triatmodjo, 1999 ) : 
$\frac{d y}{d x}=\frac{S o-S f}{1-\frac{Q^{2} T}{g A^{3}}}$

dengan :

So $\quad=$ kemiringan dasar saluran

Sf = kemiringan garis energi,

$S f=\frac{n^{2} \cdot V^{2}}{R^{4 / s}}$

Q $\quad=\operatorname{debit}\left(\mathrm{m}^{3} /\right.$ detik $)$

$\mathrm{g} \quad=$ percepatan gravitasi $\left(\mathrm{m} / \operatorname{detik}^{2}\right)$

$\mathrm{T}=$ lebar muka air $(\mathrm{m})$

A $\quad=$ luas penampang basah $\left(\mathrm{m}^{2}\right)$

Persamaan kontinuitas sedimen merupakan persamaan kesetimbangan antara volume sedimen yang masuk dan volume sedimen yang keluar pada pias yang ditinjau. Persamaan kontinuitas sedimen dituliskan sebagai (Cunge, J.A. et al ,1980):

$(1-n) b \frac{\partial z}{\partial t}+\frac{\partial G}{\partial x}=0$

$G=G(u, h)$

dengan :

$n \quad=$ porositas sedimen dasar

$b \quad=$ lebar muka air (m)

$z \quad=$ elevasi dasar sungai / saluran dari

titik referensi $(\mathrm{m})$

$G \quad=$ volume sedimen padat $\left(\mathrm{m}^{3} / \mathrm{dtk}\right)$

$\partial t \quad=$ fungsi waktu

$\partial x \quad=$ fungsi jarak

Untuk menggambarkan fluktuasi perubahan dasar saluran yang terjadi harus diketahui besaran volume transpor sedimen pada titik tinjauan. Besar volume transpor sedimen dihitung dengan menggunakan persamaan berikut:

\section{Persamaan Meyer-Peter \& Muller}

$\gamma R_{b}\left(\frac{k}{k v}\right)^{3 / 2} S-0,047\left(\gamma_{s}-\gamma\right) d_{M}=$

$0,25\left(\frac{\gamma}{g}\right)^{\frac{1}{g}} \cdot\left(q_{B}^{\prime}\right)^{2 / 3}$ dimana :

$\mathrm{d}_{\mathrm{M}}=$ diameter signifikan $(0.4 \mathrm{~mm}<\mathrm{dm}$ $<30 \mathrm{~mm}$ )

$\mathrm{R}_{\mathrm{b}} \quad=$ jari-jari hidraulik $(\mathrm{m})$

q' ${ }_{\text {в }}=$ berat angkutan sedimen dasar per satuan waktu per satuan lebar (kg/m.det)

$\mathrm{S} \quad=$ kemiringan garis energi.

$\mathrm{h} \quad=$ kedalaman aliran $(\mathrm{m})$

$\gamma_{\mathrm{s}} \quad=$ berat jenis spesifik sedimen dasar $\left(\mathrm{kg} / \mathrm{m}^{3}\right)$

$\gamma=$ berat jenis air $(=1000 \mathrm{~kg} / \mathrm{m} 3)$

$\mathrm{k}^{\prime}=\frac{26}{d_{90}^{1 / 6}} \mathrm{~m}^{1 / 3} / \mathrm{det}$

\section{Persamaan Einstein}

Jumlah partikel sedimen berukuran $d$ yang terendapkan persatuan luas dan persatuan waktu adalah :

$N_{d}=\frac{q_{b} i_{B}}{\left(\Delta_{L} d\right)\left(A_{2} d^{2} \gamma_{S}\right)}=\frac{q_{L} i_{B}}{\left(A_{L} A_{2} \gamma_{S} d^{4}\right)}$

Sedangkan persamaan (5 untuk partikel sedimen berukuran $d$ yang tererosi per satuan luas dan per satuan waktu adalah :

$N_{E}=\frac{i_{b} \cdot p}{A_{1} A_{3} d^{2}} \sqrt{\frac{g\left(\rho_{s}-\rho\right)}{d \rho}}$

Dalam kondisi keseimbangan, erosi akan sama dengan pengendapan sehingga $N_{d}=N_{C}$ atau

$\frac{q_{B} i_{B}}{\left(A_{L} A_{2} \gamma_{S} d^{4}\right)}=\frac{i_{b} \cdot p}{A_{1} A_{3} d^{2}} \sqrt{\frac{g\left(\rho_{S}-\rho\right)}{d \rho}}$

\section{Persamaan Frijlink :}

Frijlink (1952) mengusulkan persamaan sebagai berikut :

$\frac{T b}{d_{m} \sqrt{g \mu R I}}=5 e^{-0,27 \frac{\Delta d_{m}}{\mu R I}}$ 


$$
\begin{aligned}
& \mu=\left(\frac{C}{C_{d 90}}\right)^{3 / 2} \\
& C=18 \log \frac{12 R}{k} \\
& C_{d 90}=18 \log \frac{12 R}{k}
\end{aligned}
$$

dengan :

$$
\begin{aligned}
& \mathrm{Tb}=\text { volume sedimen padat tiap lebar } \\
& \text { sungai per satuan waktu } \\
& \left(\mathrm{m}^{3} / \mathrm{m}\right. \text {.detik) } \\
& d_{m} \quad=\text { diameter median }=d_{50} \\
& \mu \quad=\text { ripple factor } \\
& R \quad=\text { radius hidraulik } \\
& I \quad=\text { kemiringan garis energi. } \\
& C \quad=\text { koefisien Chezy total (butiran }+ \\
& \text { "ripple") } \\
& C_{d 90}=\text { koefisien Chezy akibat kekasaran } \\
& \text { butiran dengan diameter } \\
& \text { representatif } d_{90}
\end{aligned}
$$

Salah satu skema yang sering dipakai pada model aliran sungai adalah skema implisit Preissmann. Skema implisit Preissmann ini ditunjukkan pada Gambar 2. yang dibuat oleh Preissmann di SOGREAH dengan pendekatan deferensi sebagai berikut (Cunge, J.A., 1980).

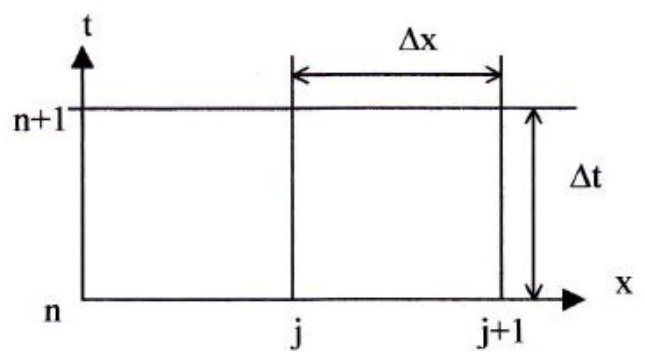

Gambar 2. Skema Implisit Preissmann

$$
\begin{aligned}
\Delta f_{i} & =f_{i}^{n+1}-f_{i}^{n} \\
\frac{\partial f}{\partial t} & =\frac{1}{2}\left(\frac{f_{i+1}^{n+1}-f_{i+1}^{n}}{\Delta t}+\frac{f_{i}^{n+1}-f_{i}^{n}}{\Delta t}\right) \\
& =\frac{1}{2 \Delta t}\left(\Delta f_{i+1}+\Delta f_{i}\right)
\end{aligned}
$$

$\frac{\partial f}{\partial x}=\theta\left(\frac{f_{i+1}^{n+1}-f_{i}^{n}}{\Delta x}\right)+1-\theta\left(\frac{f_{i+1}^{n}-f_{i}^{n}}{\Delta x}\right)$

$f(x, t)=\frac{\theta}{2}\left(f_{i+1}^{n+1}-f_{i}^{n+1}\right)+\frac{1-\theta}{2}\left(f_{i+1}^{n}-f_{i}^{n}\right)$

dengan $f$ mewakili sembarang variabel, misalkan $Q, Y, A$, di titik-titik hitungan sepanjang sungai. Indeks $i$ menunjukkan lokasi titik-titik hitungan dan indeks $n$ menunjukkan waktu dengan $n$ untuk waktu yang telah lalu dan $n+1$ untuk waktu yang sekarang. $\theta$ merupakan faktor pemberat waktu yang nilainya berkisar antara $0<\theta<$ $1(\theta=1$ untuk skema implisit, sedangkan $\theta$ $=0$ untuk skema explisit).

Penyelesaian numeris persamaan aliran membutuhkan dua kondisi batas, yaitu batas hulu dan batas hilir. Dalam penelitian ini ada tiga macam kondisi batas yang dapat digunakan di batas hulu ataupun di batas hilir, yaitu :

$Q=Q(t)$, dimana debit merupakan fungsi waktu.

$y=y(t)$, dimana elevasi muka air merupakan fungsi waktu.

$Q=f(h$ kritis $)$, dimana debit merupakan fungsi kedalaman kritis.

\section{Batas hulu}

Di batas hulu $(i=1)$ dipunyai suatu persamaan :

$\Delta Q_{1}=E_{1} \cdot \Delta Y_{1}+F_{1}$

Dimana $E_{l}$ dan $F_{l}$ harus dihitung berdasarkan informasi di titik $i=1$.

Dengan Qi = Q1 $(\mathrm{t})$ diketahui, maka :

$E_{1}=0,0$

$F_{1}=Q_{1}^{n+1}-Q_{1}^{n}$

\section{Batas hilir}

Akan digunakan 2 macam kondisi batas hilir, yaitu elevasi muka air sebagai fungsi kedalaman kritis dan elevasi muka air sebagai fungsi waktu.

(a). Apabila $Y_{N}=Y_{N}(t)$ diketahui : 
$\Delta Y_{N}=Y_{N}^{n+1}-Y_{N}^{n}$

$\Delta Q_{N}=E_{N^{*}}\left(Y_{N}^{n+1}-Y_{N}^{n}\right)+F_{N}$

(b). Apabila $Q_{N}=\mathrm{f}(h$ kritis $)$, maka :

$\Delta Q_{N}=\frac{E_{N^{*}} \int\left(Q_{N}^{i}\right)+E N \cdot Z N-E N \cdot Y_{N}^{i}+F_{N}}{1-E_{N} \frac{d y}{d Q} \cdot \Delta Q_{N}}$

dengan :

$\frac{d y}{d Q}=\frac{2}{3 \cdot g^{1 / 3} \cdot b^{2 / 3} \cdot Q^{1 / 3}}$

Untuk mendapatkan elevasi dasar saluran akibat aliran dan transpor sedimen yang terjadi, persamaan kontinuitas sedimen diselesaikan secara eksplisit dengan diferensiasi maju sebagai berikut :

$z_{i+1}^{n+1}=z_{i+1}^{n}-\frac{\Delta t\left(G s_{i+1}^{n}-G s_{i}^{n}\right)}{(1-p) \bar{b} \cdot \Delta x}$

dengan :

$z_{i+1}^{n+1}=$ Elevasi dasar saat waktu ke $n+1$

pada lokasi i+1 (meter).

$z_{i+1}^{n} \quad=$ Elevasi dasar saat waktu ke $\mathrm{n}$ pada

lokasi i+1 (meter).

$G s_{i+1}^{n}=$ Debit sedimen saat waktu ke n pada

lokasi i+1 ( meter $^{3} /$ detik).

$G s_{i}^{n} \quad=$ Debit sedimen saat waktu ke n pada

lokasi i ( meter $^{3} /$ detik).

$\Delta t \quad=$ Selisih langkah waktu (detik).

$\Delta x=$ Selisih jarak antara titik i dan

$\mathrm{i}+1$ (meter).

$\bar{b} \quad=$ Lebar muka air (meter).

$p \quad=$ porositas.

\section{METODOLOGI}

Langkah simulasi secara umum terdiri dari dua bagian, yaitu proses perhitungan hidraulika atau disebut juga dengan fase cair (liquid flow phase) dan proses perhitungan transpor sedimen yang disebut juga sebagai fase padat (solid phase). Solusi numerik dengan memisahkan antara fase cair dan padat seperti ini dikenal sebagai uncoupled solution. (Cunge, J.A. et al, 1980).
Jalannya penelitian diawali dengan penurunan persamaan kontinuitas dan momentum sehingga (didapatkan dua persamaan kerja dengan koefisien-koefisien persamaannya A,B,C,D,G dan AA, BB, CC, DD, GG. Koefisien-koefisien persamaan ini dihitung untuk setiap langkah waktu hitungan.

Kemudian dengan menggunakan metode sapuan ganda, dihitung nilai-nilai kedalaman aliran dan debit pada masing-masing titik tinjauan di sepanjang saluran. Dua persamaan pada kondisi batas, yaitu persamaan pada kondisi batas hulu dan kondisi batas hilir dirangkaikan dengan persamaan kerja yang digunakan untuk mendapatkan sapuan ke hulu dan sapuan ke hilir.

Pada kondisi dimana puncak endapan berada pada elevasi yang lebih tinggi dari elevasi muka air laut, maka kondisi batas hilir yang digunakan pada model adalah elevasi muka air kritis di atas puncak endapan. Pada bagian di sebelah hilir puncak endapan berlaku aliran permanen dan dihitung dengan menggunakan metode Euler. Pada kondisi dimana elevasi puncak endapan lebih rendah dari elevasi muka air laut, akan digunakan kondisi batas hilir berupa elevasi muka air laut yang menggambarkan keadaan pasang surut.

Setelah nilai-nilai kedalaman aliran dan debit pada masing-masing titik tinjauan didapatkan, kemudian dihitung besar volume angkutan sedimen yang terjadi pada masingmasing titik tinjauan. Besar volume angkutan sedimen tersebut dihitung dengan menggunakan persamaan angkutan sedimen Meyer-Peter \& Muller, Einstein dan Frijlink. Persamaan kontinuitas sedimen kemudian diterapkan pada masing-masing titik tinjauan guna melihat degradasi dan agradasi pada elevasi dasar saluran. Setelah kondisi dasar saluran / sungai didapatkan, maka proses perhitungan kembali pada tahap perhitungan hidraulika dengan elevasi dasar saluran yang baru. Proses ini terus berlanjut sampai endapan di mulut muara telah habis tergerus. Dalam penelitian ini akan dilihat kemampuan model dalam mensimulasikan pengerusan 
endapan di mulut muara Sungai Serang dengan data sebagai berikut :

a. Hidrograf debit banjir rencana

Hidrograf debit banjir rencana yang digunakan merupakan debit banjir rencana yang terjadi pada awal musim hujan yaitu pada bulan Oktober dan November yang besarnya ditetapkan $50 \%$ dari debit rencana tahunan (Bambang Triatmodjo, 1999).

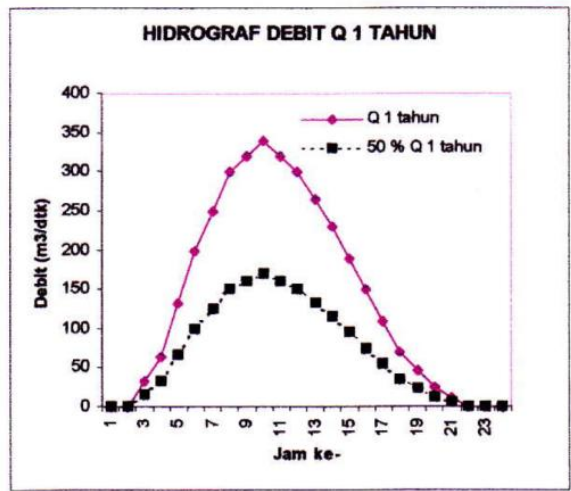

Gambar 3. Hidrograf banjir awal musim hujan Sungai Serang.

\section{Panjang Sungai}

Panjang sungai yang dijadikan sebagai daerah hitungan diambil sepanjang 2000 meter kearah hulu dari mulut muara. Pada mulut muara terdapat endapan dengan panjang pada puncak endapan searah aliran $40 \mathrm{~m}$.

\section{Dimensi saluran}

Tampang melintang sepanjang saluran dibuat seragam dengan bentuk persegi dan lebar dasar saluran 100 meter.

\section{Kemiringan dasar saluran dan endapan}

Kemiringan dasar saluran di sebelah hulu endapan dibuat seragam dengan slope $=$ 0,0005 . Untuk endapan kemiringan slope $=$ 1: 20 dengan puncak endapan berada pada elevasi $+4,00 \mathrm{~m}$. Potongan memanjang ,melintang dan skema model sungai dengan endapan pada bagian hilirnya ditampilkan pada Gambar 4. dan Gambar 5.

\section{Pasang surut}

Dari data pengukuran pasang surut selama 30 hari berturut-turut dengan interval waktu 1 jam didapat elevasi muka air berikut : (Bambang Triatmodjo, 1999)

MHWL : $+1,85 \mathrm{~m}$

MSL : $+1,05 \mathrm{~m}$

MLWL : + 0,30 m

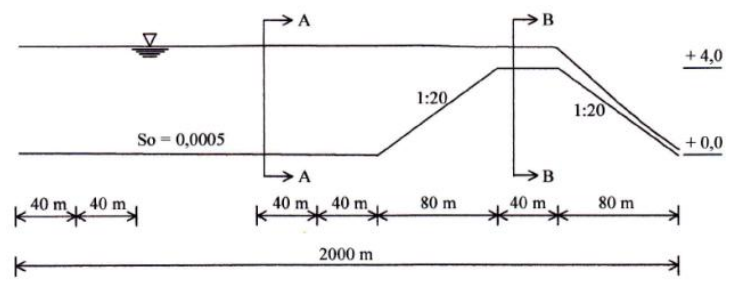

(a) Potongan memanjang model sungai dengan endapan di sebelah hilirnya

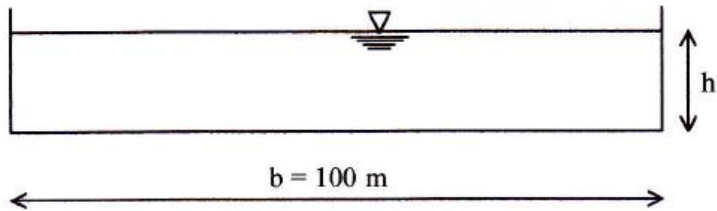

(b) Tampang Lintang Sungai di sebelah Hulu Endapan (Pot. A - A)

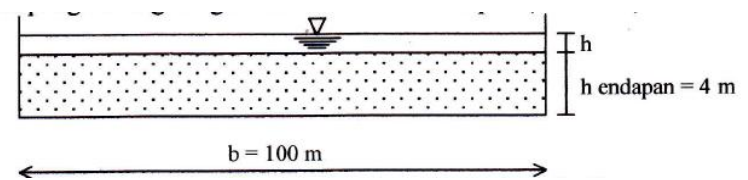

(c) Tampang Lintang Sungai di puncak Endapan (Pot. B - B)

Gambar 4. Potongan Memanjang dan Melintang Model

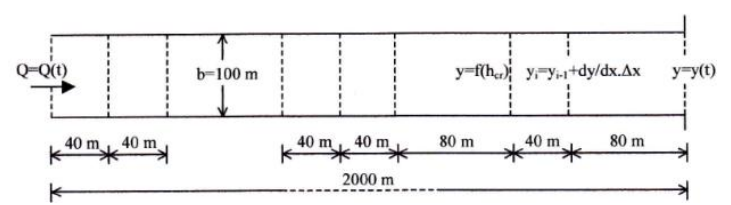

Gambar 5. Skema Model

\section{HASIL DAN PEMBAHASAN}

Dengan menggunakan kondisi steady sebagai kondisi awal, simulasi dilakukan dengan kondisi batas hulu berupa debit banjir pada awal musim hujan selama 24 jam dengan selang waktu $\Delta t=5$ detik. Setelah simulasi melebihi 24 jam, debit dari hulu digunakan debit konstan berupa Q base flow sebesar 20 $\mathrm{m}^{3} /$ detik. Hidrograf debit, perubahan elevasi muka air dan dasar saluran di lokasi puncak endapan di gambarkan pada Gambar 6 dan Gambar 7 berikut ini. 


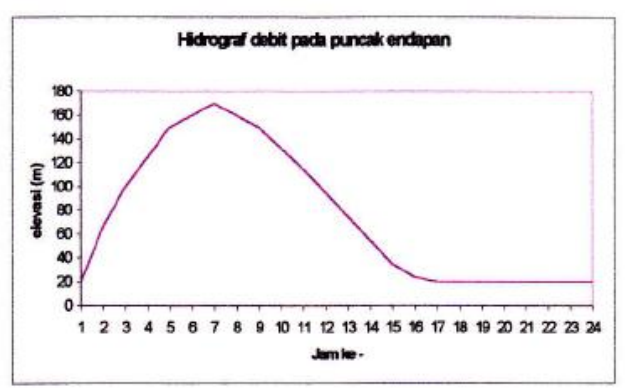

Gambar 6. Hidrograf debit di puncak endapan

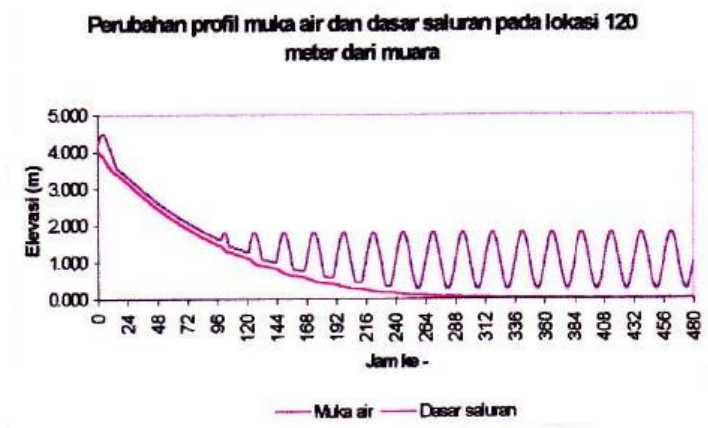

(a). 120 meter ke hulu muara

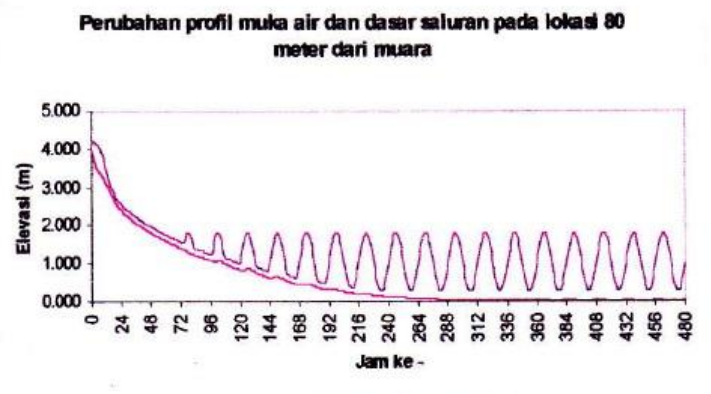

(b). 80 meter ke hulu muara

Gambar 7. Perubahan profil muka air dan dasar saluran.

Hasil simulasi menunjukkan bahwa nilai debit banjir rencana mempengaruhi fluktuasi elevasi muka air. Hal ini berpengaruh pada perubahan kecepatan aliran dan debit transpor sedimen yang terjadi. Besar debit transpor sedimen ini yang kemudian akan menentukan degradasi dan agradasi dasar saluran.

Hubungan antara parameter aliran terhadap volume transpor sedimen di puncak endapan selama 24 jam debit banjir rencana di perlihatkan pada Tabel 2 .
Tabel 2. Hubungan antara parameter aliran terhadap volume transpor sedimen.

\begin{tabular}{|c|c|c|c|c|c|}
\hline \multirow{2}{*}{$\begin{array}{l}\text { Jam } \\
\text { ke - }\end{array}$} & \multirow{2}{*}{$\begin{array}{l}\mathrm{U} \\
(\mathrm{m} / \mathrm{dtk})\end{array}$} & \multicolumn{4}{|c|}{ Volume transpor sedimen (m3/dtk) } \\
\hline & & MPM & Einstein & Frijlink & Rerata \\
\hline 1 & 1.866 & 0.014 & 0.051 & 0.021 & 0.029 \\
\hline 2 & 2.141 & 0.046 & 0.115 & 0.034 & .065 \\
\hline 3 & 2.306 & 0.078 & 0.164 & 0.041 & .094 \\
\hline 4 & 2.450 & 0.104 & 0.198 & 0.045 & 0.116 \\
\hline 5 & 2.504 & 0.112 & 0.208 & 0.047 & 0.122 \\
\hline 6 & 2.555 & 0.115 & 0.213 & 0.047 & 0.125 \\
\hline 7 & 2.504 & 0.106 & 0.201 & 0.046 & 0.118 \\
\hline 8 & 2.450 & 0.100 & 0.193 & 0.045 & 0.112 \\
\hline 9 & 2.351 & 0.090 & 0.180 & 0.043 & 0.105 \\
\hline 10 & 243 & 0.082 & 0.170 & 0.042 & 0.098 \\
\hline 11 & 2.104 & 0.073 & 0.156 & 0.040 & 0.090 \\
\hline 12 & 1.945 & 0.063 & 0.142 & 0.038 & 0.081 \\
\hline 13 & 1.754 & 0.052 & 0.125 & 0.035 & 0.071 \\
\hline 14 & 1.509 & 0.038 & 0.101 & 0.032 & 0.057 \\
\hline 15 & .326 & 0.030 & 0.087 & 0.029 & 0.049 \\
\hline 16 & 1.252 & 0.030 & 0.085 & 0.029 & 0.048 \\
\hline 17 & 1.252 & 0.033 & 0.092 & 0.030 & 0.052 \\
\hline 18 & 1.252 & 0.036 & 0.098 & 0.031 & 0.055 \\
\hline 19 & 1.252 & 0.039 & 0.103 & 0.032 & 0.058 \\
\hline 20 & 1.252 & 0.041 & 0.107 & 0.033 & 0.060 \\
\hline 21 & 1.252 & 0.043 & 0.110 & 0.033 & 0.062 \\
\hline 22 & 1.252 & 0.045 & 0.112 & 0.033 & 0.064 \\
\hline 23 & 1.252 & 0.046 & 0.114 & 0.034 & 0.065 \\
\hline 24 & 1.252 & 0.047 & 0.116 & 0.034 & 0.066 \\
\hline
\end{tabular}

Dari hasil simulasi terlihat bahwa debit banjir rencana hanya mampu menggerus endapan sebesar 20,52 dari tinggi endapan semula. Dengan menggunakan debit aliran dasar (20 $\mathrm{m}^{3} /$ detik), puncak endapan akan berada seluruhnya di bawah surut terendah muka air laut setelah hari ke 9 dari waktu awal simulasi dengan elevasi endapan pada 0.269 m. Perubahan elevasi muka air dan dasar saluran untuk setiap 24 jam ditampilkan pada Gambar 8.

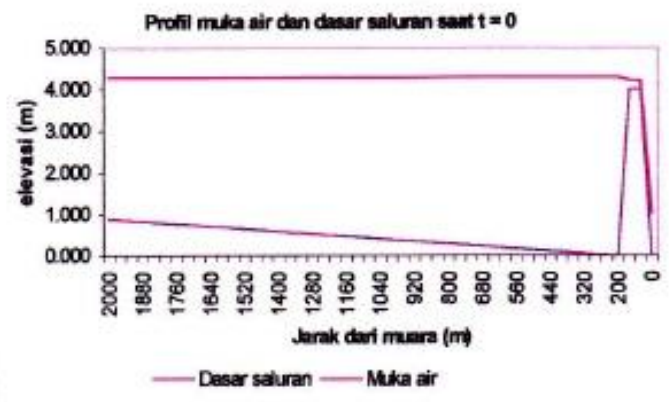


(a). $t=0$

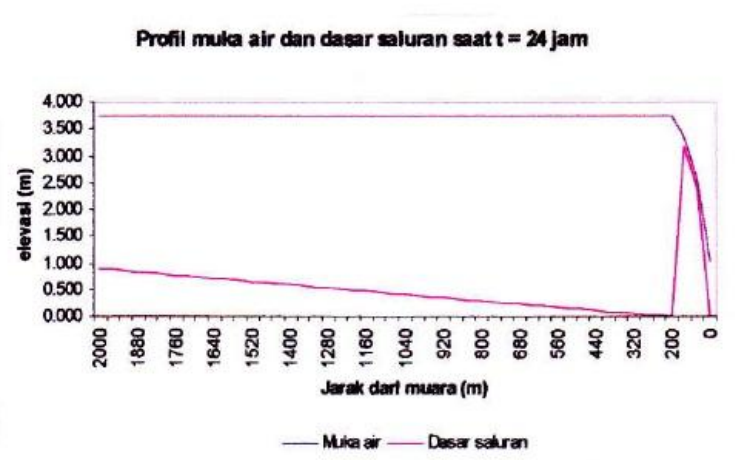

(b). $\mathrm{t}=24$ jam

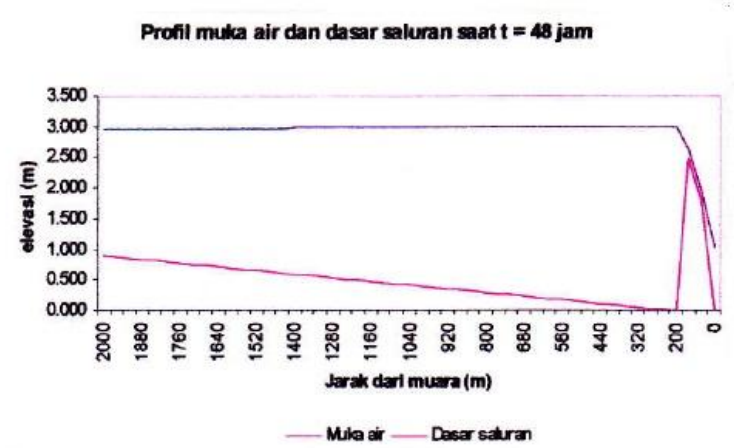

(c). $\mathrm{t}=48$ jam

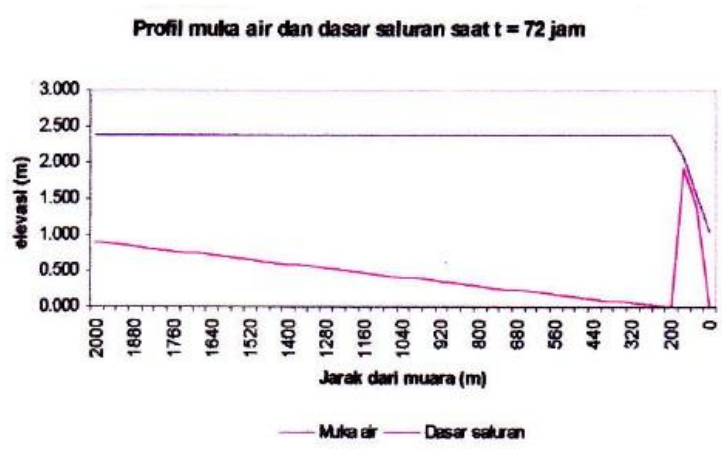

(d). $t=72$ jam

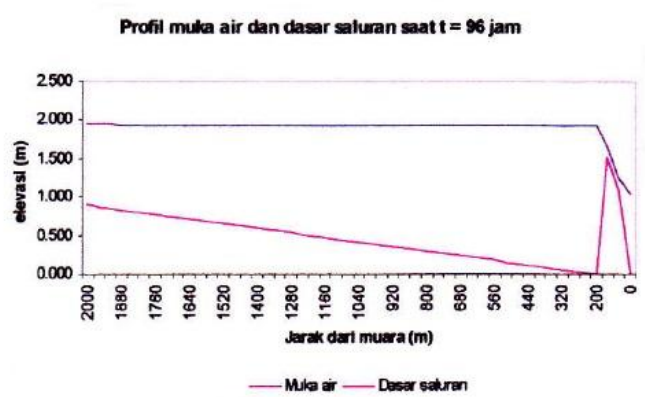

(e). $\mathrm{t}=96 \mathrm{jam}$

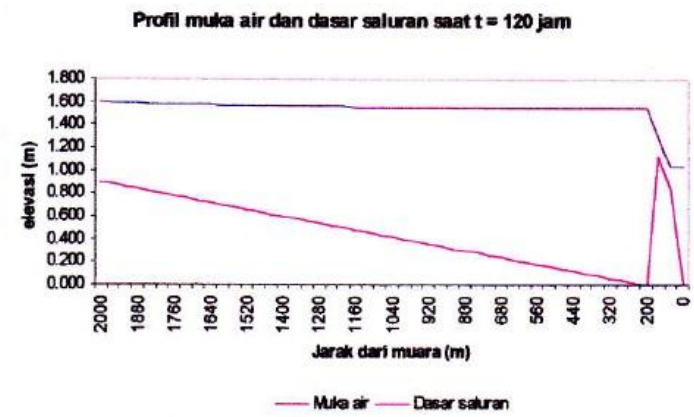

(f). $t=120$ jam

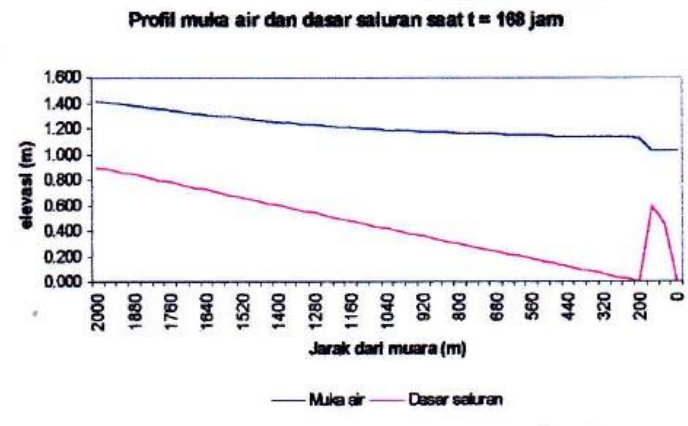

(g). $\mathrm{t}=168 \mathrm{jam}$

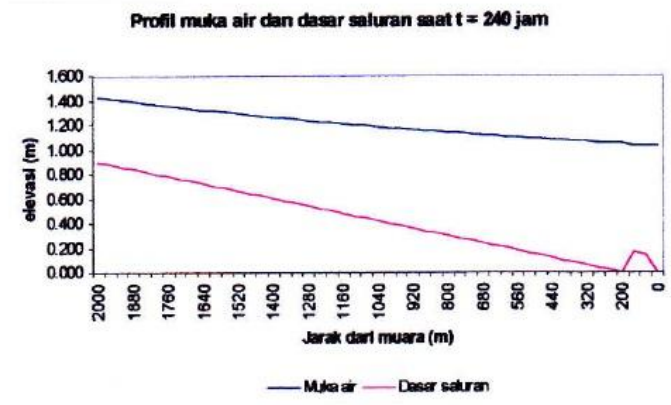

(h). $\mathrm{t}=240$ jam

Gambar 8. Profil muka air dan dasar saluran hasil simulasi

\section{SIMPULAN}

Dari hasil simulasi dan pembahasan yang telah diuraikan terdahulu, dapat disusun beberapa kesimpulan sebagai berikut :

Metode beda hingga skema implisit Preissmann dapat digunakan untuk mensimulasikan permasalahan penggerusan endapan di muara. Elevasi muka air di atas puncak endapan sebagai fungsi kedalaman 
kritis dapat digunakan sebagai kondisi batas hilir.

Dari hasil simulasi terlihat bahwa debit banjir 24 jam dengan debit puncak $170 \mathrm{~m}^{3} /$ detik mampu menggerus endapan yang berada pada elevasi $+4,00 \mathrm{~m}$ di atas muka air laut rerata sebesar 20,52 \%. Dengan menggunakan debit base flow sebesar 20 $\mathrm{m}^{3} /$ detik, dasar endapan akan tergerus dan akhirnya berada sepenuhnya di bawah elevasi muka air laut setelah 9 hari simulasi.

Pada aliran superkritik di hilir puncak endapan persamaan St. Venant sulit untuk diterapkan sehingga diasumsikan aliran yang terjadi merupakan aliran permanen. Penggunaan persamaan aliran permanen superkritik untuk setiap perubahan debit di hilir puncak endapan cukup dapat memberikan gambaran tentang perubahan elevasi dasar saluran yang terjadi akibat penggerusan.

Dari hasil simulasi terlihat bahwa volume transpor sedimen yang terjadi di muara selalu berubah mengikuti perubahan elevasi muka air dan kecepatan aliran yang terjadi. Perubahan elevasi muka air dan kecepatan aliran disebabkan karena perubahan debit di hulu sungai dan pengaruh pasang surut muka air laut.

Semakin besar kecepatan aliran semakin besar pula debit transpor sedimen yang terjadi sehingga dengan demikian lama waktu penggerusan semakin singkat.

Pada daerah hilir yang langsung berbatasan dengan air laut elevasi muka air di sungai sangat dipengaruhi oleh pasang surut. Kecepatan aliran di mulut sungai yang lebih besar terjadi saat air laut surut dan aliran menjadi diperlambat saat air laut pasang.

\section{DAFTAR PUSTAKA}

Bambang Triatmodjo., 1999, Teknik Pantai, Cetakan pertama, Beta Offset, Yogyakarta.

Bambang Agus Kironoto, 1999, Diktat Kuliah Transport Sedimen.

Budi WS, 1986, Hidraulika Numerik, Pusat Antar Universitas Ilmu Teknik Universitas Gadjah Mada, Yogyakarta.
Cunge. J. A., Holly. Jr., F. M. Verwey. A., 1980, Practical Aspects of Computational River Hydraulics, Pitman Advanced Publishing Program, London.

Djoko Luknanto, 1993, Model Matematika, Kursus Singkat Pengembangan Daerah Rawa, PAU Ilmu Teknik, Yogyakarta.

Graf, Walter Hans., 1984, Hydraulics of Sediment Transport, Water Resource Publications, Michigan.

Garde. R. J., Ranga Raju. K. G., 1977, Mechanics of Sediment Transportation and Alluvial Stream Problems, Wiley EasternLimited, New Delhi.

Koutitas, C.G., 1988, Mathematical Model in Coastal Engineering, Pentech Press, London. 